\title{
OPBOUW
}

DOOR

\section{TJ. PYTTERSEN}

\section{III}

Vervanging van levende kracht.

Suriname heeft evenals andere Amerikaansche cultuurstreken groote moeite gehad het aantal benoodigde werkkrachten op peil te houden en uit te breiden; de grootte van den aanvoer van arbeidskracht besliste omtrent de uitgestrektheid van het cultuuroppervlak.

In verband hiermede neem ik iets over uit de „Memorie van den Amerikaanschen raad over de Hollandsche bezittingen in „West-Indië in Juli 1806”, voorkomende in het Novembernummer van De W.-I. Gids, jaargang 1922.

Op pag. 395 lezen we o.m.:

„Suriname is van 1667 tot 1798 in onze macht geweest, naar hetzelfde „stelsel bestuurd en daardoor van lieverlede zeer in rijkdom en uitge„breidheid toegenomen. Van den toestand dezer kolonie, vó́rdat de En"gelschen haar in 1804 vermeesterden, valt te vermelden dat het getal in"woners bestond" uit 4000 blanken, 700 vrije lieden van de couleur, waar„onder 1000 Joden zoo blanken als vrijen en 70 à 80.000 slaven." Het aan„tal plantages vo6r 1798 beliep 500, „die thans meer dan 20 millioen kun"nen opbrengen", sedert zijn zij merkelijk vermeerderd en zullen dat nog "meer zoo maar de aanvoer van slaven blijft voortduren, waaraan echter "de Engelschen nu beletselen in den weg leggen."

En verder op dezelfde en volgende pag.:

„Het bedrag der negotatiën, op de Surinaamsche plantages verhypo„thekeerd, zal 50 millioen bedragen. Aangezien de cultures er voor meer"dere uitbreiding vatbaar zijn, moet Suriname voor het moederland van „een onberekenbare waarde worden gehouden."

Het doet dan ook vreemd aan te zien, dat in Suriname bij een cultuur als die van suikerriet met een steeds 
wederkeerenden veldarbeid van beteekenis, de vervanging van menschelijke kracht door dierlijke nimmer ernstig is betracht.

In de oude Surinaamsche literatuur zien we nu en dan wijzen op de groote waarde van ploegen voor de suikercultuur.

Zoo schrijft Vrouwe M. M. van Gelre Wed. Boxel in haar in 1735 geschreven Memorie ${ }^{1}$ ):

„Als men de rietgronden afgebrand heeft, moet men wel toesien of er alst „weer uytspruijt geen stoelen doot gegaen syn door het branden of anders „en dat bevindende moet men daer nieuwe rietstocken in steecken, dat „hiet men suppleeren.

„Als de gronden nu al eenigen tyd beplant syn geweest, moet men die „niet verlaaten alst lage kleygronden syn, maer men moet alle de oude riet„stocken uyt den grond halen en weer nadat de gronden wel om gehaalt „syn, dat men met den houw doet, maer wy hebben 1732 tot dien eynde ,een ploeg overgesonden met ordre om de oude wortels van boomen soo"veel mogelyck is uyt te laaten doen en onse landen te laaten beploegen, "dat wy hopen dat van goed effect sal syn en daer wy gedaghten van heb„ben dat men met een ploeg in een dag meer werck sal afdoen en gront „omhaalen als 50 neegers met haar houw op een dagh soude kunnen af"wercken."

Aan het slot schrijft zij verder:

„Soo wy soo gelukkig syn, dat men in Suriname met de ploegh leert om„gaan soo sal ons land onuytputtelyck syn, op de plantagie in Suriname „voortnamentlyck."

Bijna een eeuw later schrijft von Sack:

„Es kann kein besseres Land zum Pfluegen geben als in Surinam, da der „Boden ganz eben ist, und ohne Steine welche die Pflugschaar aufhalten: „leider wohnen aber die reichen Besitzer, die bei der Einfuehrung des Pflu"ges Vortheil fanden, nicht in der Colonie; wenn sie es thaeten, und der "Versuch gut ausfiele, so bin ich ueberzeugt, dass alle uebrigen Pflaenzer "bald ihren Beispiele folgen wuerden."

Von Sack neemt in het tweede deel van zijn werk een schrijven betreffende ploegmogelijkheden in Suriname over van een planter, die daaromtrent zegt:

,Wo der Boden etwas sandig ist, kann man denselben ehe man ihn mit „Zuckerrohr bestellt, mit Vortheil pfluegen vorzueglich nachdem er von „den Stuempfen und Wurzeln der Baueme gereinigt worden. In den Regel „ist aber den Boden ein sehr steifer, zaeher Lehmboden, welchen sich nicht „wohl zum Bepfluegen eignet."

1) Voorkomende in De West-Indische Gids van Mei 1922. 


\section{Von Sack schrijft nog:}

„Man wuerde von dem Pfluge, bei Bearbeitung des Landes, welches zu „Zuckerpflanzungen bestimmt ist, wesentlichen Nutzen ziehen koennen, „und es ist merkwuerdig, dass die Pflanzer der Gebrauch desselben bis „jetzt ganz vernachlaessigt haben. Zum Theil scheint diese Vernachlaes"sung ihren Grund daarin zu haben, dass es nicht nothwendig ist jedesmal "das Land zu beackern, und dass Pferde, Ochsen und Esel in den Colonie „sehr theuer sind; ueberdiess verstehen die Neger nicht mit dem Pfluge „umzugehen."

Ongeveer veertig jaar later schrijft Bosch:

„Op de plantage de Goudmijn vond ik ploegen , die echter nog niet waren gebruikt."

En dan volgt de verzuchting:

„Waarom zou men den rijken grond in Suriname, zoo in de omstreken „van Paramaribo als elders, niet op zijn Europeaansch kunnen beploegen, „en met rijst en andere levensmiddelen bebouwen? Hoe vele inwoners zou „Suriname kunnen voeden, zoo men met den grond woekerde."

M.i. bestaan er zeer aannemelijke redenen waarom het ploegen in Suriname nooit ingang heeft gevonden.

1. Bij de komst van Europeesche planters was in het land geen vee aanwezig.

2. De groote vruchtbaarheid van den grond was oorzaak, dat bij een zeer oppervlakkige grondbewerking goede resultaten werden verkregen, waardoor de planters niet genoodzaakt werden een werkwijze, wier invoering groote moeilijkheden meebracht, toe te passen.

3. Den negerslaven ontbraken de handigheid en de lust met vee om te gaan en het te verzorgen.

4. Het aanhouden van snitten was oorzaak, dat in de rietcultuur ploegen slechts zelden noodig was, omdat de terreinen ongeveer eens in de acht jaren opnieuw werden bewerkt en de overige veldwerkzaamheden niet veel beteekenden.

Dit alles neemt echter niet weg, dat door invoering van een zij het dan ook slechts gedeeltelijke grondbewerking met gebruikmaking van dergelijke trekkracht, veel handenarbeid bespaard had kunnen worden.

Dat dit in latere jaren, toen de Aziatische werkkrachten, die zeer goed met vee konden omgaan, niet gedaan 
werd, moet m. i. in hoofdzaak te wijten zijn aan het feit, dat de planters eenmaal gewend waren aan een werkwijze en er tegen op zagen om ten koste van veel geld en moeite een nieuw systeem in te voeren.

Wekunnen wel als vaststaand aannemen, dat een grondbewerking met gebruikmaking van dierlijke trekkracht ook in de toekomst in de Surinaamsche grootcultuur niet zal geschieden indien deze mechanisch kan plaats hebben.

Daar in de eerste plaats de suikercultuur een uitgebreide grondbewerking vereischt zal ik hier nagaan voor welke werkzaamheden mechanische kracht in Suriname noodig is.

Ik kan hier verder de tractortractie buiten beschouwing laten, niet omdat deze in Suriname in het geheel geen toekomst heeft, maar omdat, waar het aantal regendagen in de kolonie zeer groot is, het benutten dier tractie beperkt wordt, zoodat kabeltractie hier meer geëigend is.

Alvorens ik verder ga, moet ik er op wijzen, dat gedurende de laatste campagne op Java proeven zijn genomen met een tweede motorkabelgeulenploeg, n. l. die van de bekende engelsche firma Fowler.

De verkregen resultaten kunnen hier onbesproken blijven, daar het werk nog geheel het karakter draagt van experimenteeren, zoodat we moeten afwachten wat na het aanbrengen van wijzigingen het volgende jaar bereikt wordt.

Ik mag verder niet onvermeld laten dat Fowler met een motor van 100 P.K. werkt, waardoor hij hoopt in staat te zijn de tegenwoordig bereikte dagcapaciteit belangrijk op te voeren.

Voor Suriname zal het van vèrstrekkende beteekenis zijn, als daar bewezen wordt, hetgeen op Java bewezen is, n.l. dat in de suikerrietcultuur het zwaarste werk, dat om die reden tevens de meest werkkrachten bindt, door machines kan worden verricht en wel op den zwaarsten grond. Hiermede wordt bedoeld: het machinaal graven van hoofdgoten, het ploegen, eggen en het maken van plantgeulen. Waar op Java voldoende handenarbeid beschikbaar is voor de verdere veldwerkzaamheden is daar 
nog niet het machinaal wieden en aanaarden in ploegaanplanten toegepast. In andere cultuurstreken echter, waar ten gevolge van een chronisch gebrek aan werkkrachten voor het verrichten dier werkzaamheden, werktuigen zijn geconstrueerd, is bewezen, dat deze gunstige resultaten opleveren. Voor Suriname is het de kwestie om na te gaan in hoeverre dergelijke werktuigen met gebruikmaking van kabeltractie voldoen en welke wijzigingen er eventueel moeten worden aangebracht.

Zoo gaat het ook met de werktuigen die gebruikt worden voor het bewerken van den snit, terwijl hierbij voor Suriname verder een methode moet worden gevonden om de rietbladeren onder te werken, een oude Surinaamsche werkwijze, die daar steeds volgens de planters een gunstig resultaat heeft opgeleverd en aan welker niet-toepassing de minder goede opbrengsten in het naburige Demerary in hoofdzaak worden toegeschreven; in dit land n.l. worden de bladeren verbrand, daar men het riet vóór het snijden in brand steekt. ${ }^{1}$ )

In verband hiermede wijs ik op hetgeen Prof. Harrison uit Demerary, zegt over de waarde van een bemesting met rijststroo, welke aanhaling ik overgenomen heb uit „the West-India Committee Circular" van Jan. 19. '22.

\begin{abstract}
„The sugar-cane crops on the experimental fields of the Botanic Station „at Georgetown, Demerara, have during the last few years, been very un„satisfactory and irregular, which Sir John Harrison attributes to the ex"ceptionally heavy nature of the soil and to the difficulty of maintaining „its tilth owing to want of labour. The report of the Department of Science „,and Agriculture of that Colony for 1919 states that on these fields the sur„face dressing of rice-straw in the proportion of 12 tons to the acre has "had a marked effect in increasing the yield, the excess varying from 1, 4 "to 4,3 tons of canes per acre."
\end{abstract}

Ten einde de hier besproken vraagstukken zoo snel en zoo goed mogelijk tot oplossing te brengen, werd - als boven reeds gezegd - door mij voorgesteld om bij het uitzenden van de in mijn rapport genoemde machines eenige uitstekende technici naar Suriname te doen gaan. Eveneens heb ik er in mijn rapport op gewezen, dat de te

1) Zie omtrent het bewerken van snitten - off barring - the Louisiana Planter van 16 Sept. 1922, blz. 189. 
nemen proeven ook voor andere cultures dan die van suikerriet van groote beteekenis zullen zijn. De speciaal-machines en -werktuigen, die mede voor ander cultures reeds gedeeltelijk bestaan of vrij gemakkelijk kunnen worden geconstrueerd, moeten, zoodra gebleken is, dat de hoofdproef gunstige resultaten heeft opgeleverd, worden beproefd.

Bij dit alles moet niet uit het oog worden verloren, dat de cultures op Java om redenen in mijn rapport reeds genoemd, gebonden zijn aan werk, dat zeer hooge eischen stelt, terwijl in Suriname tengevolge van daar aanwezige bijzonder gunstige factoren volstaan kan worden met minder intensieve cultuurmethoden.

Elke vooruitgang op het gebied der levende kracht sparende landbouwindustrie zal - en ik heb hier meer speciaal het oog op de tropische en subtropische cultures - tot gevolg hebben, dat:

1. de streken, waar tot heden tengevolge van gebrek aan werkkrachten en mede tengevolge van kostbare arbeidskracht de productiekosten hoog waren, bij benutting der vorderingen dezer industrie, goedkooper zullen gaan produceeren;

2. tengevolge eener dergelijke toepassing het peil waarop die cultures tot heden stonden verhoogd $\mathrm{zal}$ worden, daar de verschillende bewerkingen beter dan zulks tot heden mogelijk was zullen worden verricht, hetgeen zal leiden tot productieverhooging met als gevolg daarvan een lageren productieprijs;

3. streken, die tengevolge van gebrek aan werkkrachten braak moesten blijven liggen, door het benutten van mechanische kracht in cultuur kunnen worden gebracht waardoor de wereldproductie wordt verhoogd, hetgeen een scherpere concurrentie op de wereldmarkten ten gevolge kan hebben.

Die oude cultuurstreken, die in hoofdzaak ten gevolge van een bijzonder gunstige arbeidsmarkt instaat waren goedkoop te produceeren, zullen die concurrentie ondervinden, temeer waar de productiekosten aldaar voortaan zeer waarschijnlijk zullen stijgen door een minder gunstig wordende arbeidsmarkt. 
Al verkeert de „nieuwe school” nog in de groeiperiode toch is het onjuist haar kracht te onderschatten als dikwijls in kringen van aanhangers der "oude school" wordt gedaan.

Indien men zich, op de hoogte houdt van de vorderingen dezer nieuwe richting in de cultures, dan valt het in de eerste plaats op met welke groote energie er wordt gewerkt om gunstige uitkomsten te verkrijgen, hoe stap voor stap terrein wordt veroverd, ziet men hoe vraagstukken wier oplossing korten tijd gelegen onbereikbaar scheen, thans opgelost zijn. In verband hiermede wijs ik op de oplossing van het vraagstuk der mechanische grondbewerking op zwaren grond welk vraagstuk volgens het rapport eener Enquête-Commissie benoemd door de leiding der Javasuikerindustrie in 1920 nog onopgelost was.

Evenzoo is het gegaan met de winning van een bruikbare kracht-alkohol voor motoren uit melasse en andere producten. Het is een onderwerp waarover den laatsten tijd zeer veel geschreven is, zoodat ik mij zal bepalen tot het aanhalen van enkele belangrijke, zeer recente uitspraken, voorkomende in de nummers van The Louisiana Planter van 5 Augustus en 16 September 1922

E. C. Freeland B. S. schrijft in zijn artikel getiteld: „The Determination of Ether in Alcohol-Ether Mixtures", o. m. het volgende:

„In those countries where supplies of gasoline are limited and prices „high, the manufacture of commercial alcohol and alcohol-ether motor fuel "from waste molasses is increasing very rapidly, and the use of this fuel is "finding favor in almost every sugar-producing country. At present, enor"mous quantities of available fuel are being thrown away by sugarcen"trals."

Hij verwijst dan naar hetgeen Dr. Prinsen Geerlings jaren geleden gezegd heeft omtrent de toenmalige waarde van melasse en gaat dan verder als volgt door:

\footnotetext{
„Although this is still the general method of disposing of the molasses „at the present time (n.l. het laten wegloopen van het afvalproduct.), yet „numbers of surgarcentrals are converting it into power spirit and a still "larger number contemplate doing so in the near future. There are many "uses for which internal combustion engines can be employed on sugar plan„tations and the cost of fuel supplies has no doubt prevented a number of es-
} 
„tates from using agricultural machinery ${ }^{1}$ ). Besides producing power spirit „for their own use, sugarcentrals have started the production of alcohol„ether motor fuel for use in motorcars as a substitute for gasoline."

In het tweede artikel, waarin Mr. Forster, headchemist of Maui Agricultural Co's Mill at Paia (Sandwicheilanden), als uitvinder van den motor-alcohol genoemd wordt, lezen wij o. $\mathrm{m}$. het volgende:

„It takes from $2 \frac{1}{2}$ to 3 gallons of molasses to make one gallon of alcohol ,and the total cost of the alcohol, of course, fluctuates with the market „price of molasses." 2 )

Schrijver wijst er dan op dat de alchohol voor motoren gebruikt wordt en dat de grondstof vroeger vrijwel waardeloos was:

„Now it is all utilized and there is a demand for more."

De toestellen voor het fabriceeren van dit nieuw product worden o.m. op de markt gebracht door „The Walter E. Lummus Co. Builder of Improved Alcohol-Ether Plants, 173, Milkstr. Boston", die het volgende adverteeren:

„Economical Plant for Fuel Alcohol.

"The use of alcohol as a motorfuel has emerged from the experimental „stage and now engages the interest of sugarproducers as a practical means "of utilizing their waste molasses. enz."

Dat men hier met feiten te doen heeft, bewijst een berichtje uit de laatst ontvangen $\mathrm{L}$. Pl. van 7 October onder het hoofd: „Cuban Motor Spirit Seeks Foreign Market", en waaruit ik het volgende overneem:

„That Cuba's motor spirit manufacturers, who make their product from the Cuban final molasses, are earnestly seeking other fields for the disposal of their output was manifested during the past week, when S. S. Maasdam sailed for Rotterdam, Holland, which a cargo of motor spirits made in $\mathrm{Cu}$ ba. This motor spirits will be tested out in Holland with the view of replacing the high priced gasoline, used as fuel in internal combustion engines.

.... Gasoline which sold just before the motor spirits was put on the

1) Cursiveering door mij. P.

$\left.{ }^{2}\right)$ Sedert dit artikel geschreven werd - November 1922 - zijn meerdere belangrijke gegevens gepubliceerd geworden over Foster-fuel. In „the L. Pl." van 16 Dec. 1922 e. v. komt een artikel voor getiteld: „A Report on the manufacture of industrial alcohol from Hawaiian molasses." 
market in Havanna last July for 54 cents per gallon, is now being sold for 37 cents per gallon, while motor spirits, which by volume has about $60 \%$ of the mileage of gasoline, is selling for 19 to 20 cents per gallon, and is not causing any engine troubles such as gasoline does, and such as was thought at first the motor spirits would cause. It has also been stated here that some of the larger petroleum refiners are considerably concerned at the decrease in the consumption of gasoline which has taken place during the past year in the West-Indies, where alcoholic motor spirits is being used in place of gasoline." 1)

Van bevriende engelsche zijde bereikte mij het bericht dat enkele der suikerfabrikanten in Britsch West-Indië, die kleine ondernemingen bezitten, welke niet uitgebreid kunnen worden en die derhalve een hoogen productieprijs hebben, het plan hebben opgevat om al het rietsap te verwerken tot krachtalcohol.

Ook voor de Java-suikerindustrie kan wellicht voor sommige ondernemingen, die een hooge brandstofrekening hebben, de nieuwe vinding van nut zijn.

\section{Boschexploitatie.}

Vele goede houtsoorten komen in de Surinaamsche bosschen voor, die tot heden in vrij kleine hoeveelheden worden uitgevoerd. Ik waag mij niet aan een voorspelling omtrent de toekomst eener boschexploitatie, maar wil er hier de aandacht op vestigen, dat de kosten van ontginning van de bosschen voor landbouwdoeleinden kunnen verminderd worden door den verkoop der goede houtsoorten. Verder wil ik er even op wijzen, dat voor het uitslepen der boomstammen naar de hoofdtransportwegen kabeltractie reeds wordt toegepast, welke ook voor verder van de hoofdtransportwegen gelegen terreinen goede diensten zal kunnen bewijzen.

\section{Veeteelt.}

De veeteelt in Suriname is wel van zeer weinig beteekenis, hetgeen terstond in het oog springt, als men

1) Cuba produceerde gedurende de campagne 1921/22 25 millioen liters motorspirit, terwijl wordt aangenomen dat de suikerfabrieken aldaar 200 millioen liters jaarlijks kunnen maken. 
bedenkt, dat in dit land met zijn kleine bevolking van slechts honderdduizend inwoners de vleeschconsumptie grooter is dan de productie, zoodat geregeld slachtvee van buiten moet worden ingevoerd. Het is te hopen, dat de maatregelen, die genomen worden om de veeteelt uit te breiden, spoedig het succes mogen hebben, dat het land in eigen consumptie zal kunnen voorzien. Zoodra de productie de consumptie overtreft gaat het er voor de veehouders anders uitzien, daar deze dan verplicht zullen zijn op naburige markten voor hun surplus afzet te zoeken, waar zij dan in concurrentie zullen komen met handelaren, die deze markten reeds lange jaren bedienden en dus een grooten voorsprong hebben.

De vraag die ik hier wensch te behandelen is, of Suriname de factoren bezit noodig voor het slagen van groote veebedrijven.

De voor de oplossing noodige gegevens kunnen grootendeels verkregen worden uit hetgeen omtrent dit onderwerp reeds door den ijverigen en bekwamen beheershoutvester in Suriname, den heer J. W. Gonggryp, werd gepubliceerd in Bulletin No. 43 Juni 1921 van het Departement van den Landbouw in Suriname en in een in De West-Indische Gids van Mei 1922 voorkomend artikel getiteld: „Over het Orinoco gebied.”

Veel in Suriname en Venezuela, zegt de heer G., komt overeen; het groote verschil is er door de menschen gebracht. De Hollanders, meer speciaal de Zeeuwen, hebben zich in het lage kustgebied van Suriname achter polderdijken teruggetrokken, waar zij hun plantagecultuur dreven, terwijl de Spanjaarden precies het omgekeerde deden, daar deze bezit namen van de hooge savanna's en Ilano's, die hen herinnerden aan de steppen van Andalusië, beroemd om de teelt van paarden en vechtstieren.

Ik ben er van overtuigd zegt gen.heer, dat als de Spanjaarden toevallig in Suriname waren terecht gekomen, en wij in het Orinocogebied, Delta Amacuro cultuurcentra zou hebben gekregen als men nu in Suriname en Britsch Guyana heeft, terwijl de Surinaamsche savanna's, waar thans geen enkel stuk vee loopt, bevolkt zouden 
wezen, met de kudden die den voornaamsten rijkdom van den Staat Bolivar uitmaken.

Die veerijkdom in Venezuela bedroeg in 1804 1.200.000 - in 19012.00 .000 - en op het oogenblik ongeveer 2.600.000, stuks.

De uitvoer van levend hoornvee uit dit land was.

1915. 18.339 stuks. $\quad 1917.18 .333$ stuks.

1916. 18.267

1918. 19.020

De uitvoer van bevroren vleesch bedroeg in die jaren resp.: 2. 197.240 KG., 3.315.990, 4.978.420, 5.867.770.

De oppervlakte van de Surinaamsche savanna's is volgens den heer G. zelfs niet bij benadering op te geven. Hij taxeert de oppervlakte op minstens verscheidene honderdduizenden hectaren en in de plaats van, zooals nu vee voor de locale consumptie te moeten invoeren, zouden wij van Suriname een vee-exporteerend land kunnen maken.

De beste grassoort, het „tupuquen”, der Venezolaansche savanna's wordt eveneens aangetroffen op de Surinaamsche, terwijl de wilde savannagrassen ook in beide landstreken dezelfde zijn.

Het streven van de veehouders op de veehouderijen of hato's in Venezuela is voor een groot deel echter erop gericht om de dieren zoo tam te maken, dat zoo min mogelijk van de lasso moet worden gebruik gemaakt.

Een economisch gebruik van de werkkrachten is noodzakelijk. Men rekent dat een beheerder met een drietal "peons" (arbeiders) een hato van een paar vierkante uren gaans, met 1000 stuks vee moet kunnen beheeren. Hoofdzaak bij de bedrijven van Venezolaansch Guayana is de teelt van slachtvee en het is in dit verband wel opmerkelijk, dat het slachten van vrouwelijk vee in de republiek absoluut verboden is, lezen wij verder.

Wat in Venezuela bereikt is, kan in Suriname bereikt worden; er kan misschien meer bereikt worden als onze energieke ondernemers er de schouders onder willen zetten. Ook de Engelschen in het tusschen beide landen gelegen Demerary zien in een groot veebedrijf in hun kolonie, waar ongeveer dezelfde factoren worden aangetroffen, toekomst. 
De heer G. heeft aan de mij gedane toezegging om het gewicht van luchtdroog savannagras te bepalen voldaan door op Zanderij 1 (Gouv. reserve) twee bundels gras, die versch $18 \mathrm{KG}$. wogen, na droging te wegen, waarbij de uitkomst was, dat die bundels onderscheidenlijk $53 \%$ en $54 \%$ in gewicht teruggegaan bleken te zijn; per HA. omgerekend, bedroeg de hoeveelheid gras op beide proefvlakken:

$$
\begin{array}{lll}
\text { versch } & 2550 \mathrm{KG} \text {. en } 4475 \mathrm{KG} \text {.; } \\
\text { luchtdroog } & 1360 \mathrm{KG} \text {. en } 2400 \mathrm{KG} \text {. }
\end{array}
$$

Uit een: „Kort verslag van een reis over de savannastreek tusschen Coesewijne en spoorbaan ter hoogte van Saron en Poika-kreek aan de Saramacca", door bedoelden heer $\mathrm{G}$. opgemaakt, neem ik hier het volgende over:

„De reis werd ondernomen in hoofdzaak om een indruk te krijgen van de „savanna's aan de Coesewijne in de nabijheid van de Zeekoekreek en..... ; „om met de Indianen van Poika te bespreken in hoeverre zij de veeteelt op "de savanna in de nabijheid van hun kampen zouden willen ter hand ne„men; en om de savanna's van de geheele streek in oogenschouw te ne„men."....

....,De savanna's tusschen Poika en de Coesewijne ter hoogte van de „monding van de Goliathkreek en tusschen Saron, Matta en Zanderij 1 zijn „hoog gelegen, worden nooit overstroomd, ongeschikt voor cultuur wegens „ten eenen male onvoldoende vruchtbaarheid, doch bruikbaar, voor een „groot deel zelfs zeer geschikt, voor veeteelt zooals in Venezuela uitge„oefend. De savanna tusschen de Saramacca en de spoorbaan is zandiger „en heeft minder gras en meer struikgewas dan de Coesewijne-savanna, „doch is rijk aan Mauritie-palmen en is stellig niet minder bruikbaar dan „vele Venezolaansche savanna's. .... Een geheel ander karakter dragen „de savanna's langs de Coesewijne tusschen de Zeekoekreek en de Pan„kreek en hooger. De grond is hier kleiachtig, soms met veel kaolien en „taai als stopverf, dikwijls lichter en met groffere deelen vermengd. Langs „de kreek is het terrein het hoogst, thans ongeveer $\frac{3}{4} \mathrm{M}$. boven water, en „daalt naar mate men zich van den oever verwijdert, terwijl de kleiachti"ge oppervlakte plaats maakt voor een aanvankelijk slechts dunne laag „veen of begassie. .... In den regentijd staat het geheele land ongeveer „een meter diep onder water.... De overstrooming zou volgens den op„zichter van het boschwezen ongeveer 3 à 4 maanden van het jaar du"ren. .... Z Zoolang het terrein niet overstroomd is, zullen groote gedeelten „ervan dus wel voor veeteelt in aanmerking kunnen komen."

Naast de savannastrook, die bezuiden het alluviale kustgebied voorkomt, en zich vrijwel over de geheele 
breedte der kolonie uitstrekt, komen in het achterland van Suriname in de nabijheid van de Braziliaansche grens savanna's voor waaromtrent zeer weinig bekend is.

Op den overgang van zand op klei worden hier en daar leemsavanna's aangetroffen, die van waarde kunnen worden voor de veeteelt indien zij beschermd worden tegen al te zware langdurige overstoomingen, terwijl dan verschillende dezer vlakten tevens voor cultuur kunnen worden benut.

De verder zeer uitgestrekte kleisavanna's in het kustgebied zullen indien zij ingedijkt, gedraineerd en met paragras beplant worden, hetgeen alles met niet groote middelen kan geschieden, per vlakte eenheid heel wat meer vee kunnen voeden dan de zandsavanna's.

Hierbij komt nog, dat waar een zeer groot deel der kleisavanna's gunstige factoren bevatten voor verschillende cultures, hier gemengde bedrijven van cultuur en veeteelt kunnen ontstaan. ${ }^{1}$ )

Verder moet ik er op wijzen, dat in het algemeen de veestapel per vlakte eenheid verhoogd kan worden door benutting van palmvruchten. Een deel der savanna's wordt omgeven door bosschen waarin dikwijls palmboomen overheerschen. De vruchten dezer boomen zijn in vele gevallen een zeer goed veevoer, zooals ik reeds vroeger in mijn publicatie's uit oude schrijvers heb aangetoond.

Ter nadere bevestiging wijs ik hier op hetgeen Lans daaromtrent schrijft in zijn:

„Bijdrage tot de Kennis der Kolonie Suriname”. (1842), waaruit ik het volgende overneem.

„In Boven-Cottica en in Para waren eenige ossen der houtgronden, in „de bosschen aan de dienstbaarheid ontvlugt; men veronderstelde dat zij "door de tijgers moesten zijn verscheurd. Na verloop van eenige jaren wer"den zij ontdekt van tijd tot tijd geschoten en eenige opgevangen. Volgens "de door mij ingewonnen rapporten, waren zij alle in uitmuntenden toe„stand. Een derzelve is in het jaar 1836 of 1837 te Paramaribo geslagt; "dezen heb ik met veel belangstelling gezien, en allen die met mij in het„zelfde geval geweest zijn, zullen erkennen, dat dit dier alle kenmerken

1) Het beenderstelsel van op kleisavanna's gefokt vee is krachtiger dan dat op zandsavanna's. 
„droeg van volmaakte gezondheid, kracht en overvloedige voeding. Op„merkelijk was de ruigheid van zijn huid, vooral aan den kop en de ver„bazend zware schoft. Zijn onrustige blik en zware hals zouden, ware het „mogelijk geweest, hebben kunnen doen veronderstellen, dat het een afge„dwaald beest was van een Brasiliaansche kudde. Het vleesch was bijna „oneetbaar door het overvloedige vet; hetgeen waarschijnlijk aan de over"matige voeding met palmvruchten moet toegeschreven worden ${ }^{1}$ ). Waren deze "weinige beesten, in plaats van ossen, koeijen en stieren geweest, dan zou „men hoogstwaarschijnlijk, tenminste indien men ze den oorlog niet had „aangedaan, reeds door het toeval eenigermate verwezentlijk zien, dat „wat ik thans voorstel, om planmatig te doen geboren worden: de vrije of ",halfvrije veeteelt in de Surinaamsche bovenlanden."

De meer aangehaalde Dominee Bosch schrijft nog iets dat hier op zijn plaats is, n. 1 .

„De plantaadje Overtoom (Parastreek) levert een gezigt op, hoedanig „,ik op Suriname niet dacht te vinden. Rondom het huis ligt een groote Sa„vane van heuvelachtig land, waar op een groot aantal hoornvee graasde."

$\mathrm{Nu}$ ik het over de waarde van palmvruchten voor de veeteelt heb, kan ik even blijven stilstaan bij de cocoscultuur, die herhaaldelijk genoemd wordt samen met de veeteelt.

In het Maartnummer, 1922, van De W.I. Gids heb ik deze cultuur en de veeteelt even besproken.

Bekend is, dat op Coronie de cocospalm en het vee beide goed aarden.

Of dat in andere deelen der kolonie eveneens het geval zal zijn valt te betwijfelen daar hartrotziekte en torren de palm hevig aantasten.

Blom schreef in 1805 over deze cultuur en de ,wurmen” het volgende:

„Tegen de Wurmen die de Cocosnote Boomen tot in het Merg door knagen waarna de Boom in het middenste of binnenste tot rotting komt en uitgaat...."

Hij noemt ter bestrijding dezer plaag het sap van de "Aloë Semperviva".

Verder schrijft hij:

. dog de Kokosnoot, in de Vaste Klij na bij Water het zij Rivier, Creecq, Sloot, Trens of Swamp geplant, komt zeer zelden goed voort, deeze Boom bemind, verre van het Water in hoog droog veen, Leem, of zandige Aarden te zijn geplant."

1) Cursiveering door mij. P. 
Onder de cocosboomen voorkomende op nederzettingen van Creolen in het Boven-Surinamegebied zag ik er, die eveneens aangetast waren. De stand der boomen hoewel niet slecht viel mij na alles wat ik er over gehoord had, niet mee. Deze boom aardt zeer zeker in de kolonie, maar vereischt meer verzorging dan in Oost-Indië, al zijn er streken in Suriname waar deze verzorging tot een minimum gereduceerd kan worden.

Het bovenstaande leidt tot de gevolgtrekking dat een groot opgezette zoowel extensief als meer intensief gedreven veeteelt in Suriname levensvatbaarheid kan bezitten.

Waar zonder het vastleggen van aanzienlijke bedragen voldoende gegevens kunnen worden verkregen voor een betrouwbare rentabiliteitsberekening, meen ik er op te mogen aandringen, dat de Regeering pogingen in die richting met de haar ten dienste staande middelen steunt.

De uitvoer van een groot veebedrijf zal omvatten: huiden, vleesch - waarvoor koelinrichtingen noodig zijn - en producten uit afval verkregen.

(Wordt vervolgd). 